\title{
The Roles of the Ministry of Marine and Fishery in Marine Environment Protection from Oil Pollution by Tankers in the Sea in Indonesian Legal System
}

\author{
Elly Kristiani Purwendah, ${ }^{1-}$ Marsudi Triatmodjo, ${ }^{21}$ Linda Yanti Sulistiawati ${ }^{2}$ \\ ${ }^{1}$ Mahasiswa Doktoral Ilmu Hukum, Fakultas Hukum Universitas Gadjah Mada, Yogyakarta, \\ Indonesia \\ 2 1,2 2 Fakultas Hukum, Universitas Gadjah Mada Yogyakarta, Indonesia
}

\begin{abstract}
Aabstract. The Ministry of Marine and Fishery (KKP), as stipulated in the Presidential Regulation Number 2 of 2017 on the Amendment of the Presidential Regulation Number 63 of 2015 on the Ministry of Marine and Fishery, is in charge of organizing government affairs in the field of marine and fisheries to assist the President in organizing the state government. In one of the seven pillars of Indonesia's marine policy, which is in the pillars of the management in the scope and protection of marine environment, one of the major programs of marine environment protection policy is the prevention, mitigation, and recovery of pollution impacts and damage to marine environment. For the achievement of the objectives, the KKP requires a normative support for the protection to marine environment from oil pollution by tankers, in terms of prevention, mitigation, and recovery of pollution impacts and damage to marine environment.
\end{abstract}

\section{Introduction}

Indonesia's marine territory which reaches an area of 5.8 million $\mathrm{km}^{2}$ makes the marine sector potential become invaluable, particularly from the sector of marine natural resource. [1] The potential of marine resources is so important that it is prioritized by Indonesia in the concept of green economy and blue economy that leads to sustainable development as conveyed by the President of the Republic of Indonesia during his speech at the Conference of Rio+20 (the United Nations Conference on Sustainable Development) in Rio de Janeiro, Brazil, on June 20-22, 2012. [2] The marine environment is part of a country's economy. [3] It is estimated that the Indonesia's marine potential reaches US\$171 billion per year. In detail, it can be stated as follows; Fisheries: US\$ 32,000,000,000/year (IPB, 1997), Coastal Area: US\$ 56,000,000,000 per year (ADB 1997) Biotechnology: US\$ 40,000,000,000 per year (PKSPL-IPB, 1997), Marine Tourism: US\$ 2,000,000,000 per year (DEPBUDPAR, 2000), Petroleum: US\$21,000,000,000 per year (ESDM 1999), and Marine Transportation:

${ }^{1-}$ Correspondence author; elly_kristiani@yahoo.co.id 
US\$ 20,000,000,000 per year. [4]

The promising condition of the Indonesian sea remains untouched. Hence, the government issued Law Number 32 of 2014 on Marine and the State Gazette of the Republic of Indonesia of 2014 Number 294 in which in Chapter VI on Marine Management Article 14,it states that the Government and the Regional Government in accordance with their authority conduct marine management for the greatest prosperity of the people through the utilization and exploitation of marine resources by using blue economic principles. The blue economy policy adopted by the state certainly causes the consequences for the state to prepare a national legal system related to the state's obligation to develop marine science and inter-state technology in terms of exploration, conservation and processing of marine resources, the protection and preservation to marine environment, marine science research and other activities in marine environment in accordance with the United Nations Convention on the Law of the Sea (UNCLOS). With the aim of accelerating social and economic development for developing countries. The State should strive to create a climate of "economic law" and "favorable law" for the transfer of marine technology that benefits all relevant parties fairly (Article 266 Paragraphs 2 and 3 of UNCLOS).

Furthermore, the most important safeguard in a legal system for the sustainability of its marine resources against exploration,the protection to exploitation activities, and the destruction and pollution of marine environment is stated in Article 193 which states that "states have sovereign rights to exploit their natural resources in line with environmental policies as well as their obligations to protect and preserve marine environment. A good and just legal system that stands for the sustainability and preservation of marine environment is of course a judicial system with an insight on a value of ecological justice that has a perspective on deep ecological concept by prioritizing the marine environment right as the central part of law enforcement system. Marine environmental rights as a central legal system is surely a point of interest that needs to be protected for human needs as the objective of the law is the conflict of human interest. Therefore, the law that is coherent with environmental justice in the concept of blue economy should be regulated in a unity of national legal system in order not in contrary with the interests of economic exploitation which results in the destruction and pollution of marine environment resources. To realize a good and fair legal system and takes sides for the sustainability and preservation of the sea, a legal structure that can play an active role in law enforcement is required.

Some marine areas in Indonesia have certain characteristics, such as the presence of fishermen, ports with their function of sea transportation and trade, and the exploitation of natural resources such as petroleum. This is in accordance with the geographical condition in the Cilacap sea that is vulnerable to oil pollution caused by oil companies.For example, in Cilacap, in one time, there are two pollution cases happened; one from the Single Point Moring (SPM) of PT. Pertamina RU. IV on May 20, 2015, and the second one from the Martha Petrol Ship on May 24, 2015. The oil distribution moves towards the southern island of Nuksakambangan and Teluk Penyu beach and surrounding areas. The pollution certainly caused direct victims which were very disadvantaged economically because fishermen can not catch fish in Cilacap waters.

This paper will discuss how the Ministry of Marine and Fishery plays the role of protecting the interests of marine ecosystem from tanker oil pollution that can lead to decreased quality of marine fisheries and fishermen's welfare. The role is whether the Ministry of Marine and Fishery can help calculate the loss of fishery and the carrying capacity of its ecosystem and how its implementation mechanism. 


\section{The Setting of Marine Environment Protection from Oil Pollution by Tankers}

The Indonesian sea has a tangible economic value, such as; fisheries, shipping, offshore mining, health and biodiversity and marine tourism. These economic interests require enhanced marine infrastructures. [5] Various programs in implementing marine policy strategies are required, such as the preparation and development of marine economic data and information base, the creation of a conducive and efficient business investment climate, the development of business world in the national maritime field with international competitiveness, the development of marine economic area in an integrated manner, the blue economic principles in coastal areas, small islands, outer islands and Indonesian waters realistically, optimizing the provision of infrastructure facilities required by the business world and marine business actors particularly fishermen, intensification, extensification and reinforcement of fishery products ranging from pre-production process up to marketing, development of mutually beneficial marine business partnership between small and medium enterprises with big business, and the development of sustainable economic cooperation with marine strategic partner countries. [6]

It became a serious problem when marine economy is superior with all forms of strategic program is implemented. This will be related to the shipping and trading sectors, petroleum and community welfare in the fishermen and fishery sector,and marine environment. Given some of the relevant interests, it will also relate to law enforcement structures. On the one hand, related to the shipping, it will be the authority of the Ministry of Transportation which is, in this case, the Directorate General of Sea Transportation. It will be then related to petroleum with the Ministry of Energy and Natural Resources, and it is lastly related to the welfare of fishermen and fishery communities which will be under the authority of the Ministry of Marine and Fishery. Marine environment as an important matter as the impact of marine economic development will be related to the authority of two major ministries; the Ministry of Environment and Forestry and the Ministry of Marine and Fishery. Problems arise when Marine Law provides protection to traditional fishermen.On the other hand, it also develops the potential of marine and industrial transportation.

It can be seen in the condition of the coastal area of Cilacap which has the characteristics with the presence of the State Owned Company of PT. Pertamina Ru. IV as an oil processing unit and Tanjung Intan Port. Tankers as a means of sea transportation may cause oil pollution in the coastal areas and harm the welfare of fishermen. [7] The three priorities of marine economic development make the Cilacap Sea vulnerable to the pollution of oil sources from tankersgiven the distribution of oil is carried out through sea transportation.

It is argued by John Maddox [8] that pollution will be solved by calculating the price. Pollution is an economic problem: "we can reduce pollution if we are prepared to pay it". Then, it must be understood that the problem of pollution is an economic problem, meaning how much we pay by creating anti-pollution prevention tools or indirectly by paying for the losses caused by pollution. H.C. Combs ${ }^{5}$ argues that economic changes can solve many environmental problems. According to him, pollution can be controlled economically through legal arrangements, such as the application of fines and taxes on the materials processed or waste.

The Shipping Law provides an understanding of the prevention and countermeasures of pollution from the operation of vessels provided for in Article 227 by stipulating that; each vessel shall prevent and overcome the occurrence of environmental contamination sourced from ships. Operated ships of a certain type and size shall be equipped with the equipment and materials of oil pollution prevention with the approval from the government. Operated 
ships of a certain type and size shall be accompanied by a pattern of oil pollution control from the ships authorized by the government. The size of the required vessel with an obligation to complete the pollution control shall be further stipulated in the Regulation of the Minister of Transportation of the Republic of Indonesia No. 45 of 2012 on Ship Safety Management, for oil tankers, chemical tankers, and gas carriers with the gross tonnage greater or equal with GT 150 (one hundred and fifty Gross Tonnage).

The Ministry of Marine and Fishery (KKP) is established through the Presidential Regulation No. 63 of 2015 on the Ministry of Marine and Fishery and the State Gazette of the Republic of Indonesia of 2015 Number 111. The discussions will begin with how the Indonesian legal system protects the sea from tanker oil pollution through various regulations. The protection to marine environment is very important to protect the marine ecosystem as Indonesia's marine areas which are very potential for economic growth. Oil pollution is regulated in various regulations in the Indonesian legal system. The regulation of oil pollution in Indonesian law is Law Number 32 of 2014 on Marine and the Supplement to the State Gazette of the Republic of Indonesia Number 5605. In Article 1, point 2 , it is stated that the protection to marine environment is a systematic and integrated effort undertaken to conserve marine resources and to prevent the occurrence of pollution and/ or environmental damage in the sea that includes marine conservation, marine pollution control, disaster management, pollution prevention and handling, and damage and disasters. In article paragraph (2), point $b$, it explains that marine disaster caused by environmental pollution can be oil pollution.

Since the beginning, the KKP considers pollution as a complementary task since the main task of pollution control is within the authority of the Ministry of Environment and Forestry (KLHK). In the Presidential Regulation No. 109/2006 on the Emergency Response of Oil Spill at the Sea made for the sake of quick, precise and coordinated action of shipping activities, oil and natural gas exploitation activities and other activities that contain the risk of accidents and may result in oil spills which can pollute and / or damage the marine environment by mobilizing local, regional and national potentials effectively. The Chairman of the National Disaster Management Team is the Minister of Transportation, and the Minister of Marine and Fishery as the member. The KKP, together with other Ministries (Ministry of Environment and Forestry), is the facilitator representing the government's interest in solving oil pollution problem due to tankers.

In the case of tanker's spill in Cilacap in 2015, the KKP had no active role in facilitating the demands for fish losses against the losses in fishery sector. The sampling and field verification were conducted by KLHK. [9] However, on October 18, 2016, the KKP had a Pollution Handling Team established through the Decree of the Minister of Marine and Fishery of the Republic of Indonesia Number 5/ KEPMEN-KP / 2016 on the Oil Spill Response Team on Marine Resources and Fisheries.

This team was established to overcome and compensate for the oil losses at sea due to marine and natural gas shipping and the concession activities that pollute and damage marine and fishery resources. The team consists of directors, working groups and field personnel. The Steering Committee was tasked to coordinate the implementation of the countermeasures in overcoming the impact of oil spill of marine and fishery resources.

The working group consists of, first,the working group of data-base and data and material collection containing the data-base of marine resources, coastal fishery and Indonesian waters. They also compile environmental sensitivity index maps; calculate the economic value of marine resources,coastal fishery, and Indonesian waters; compile the fixed procedure on material and information collection; conduct the pull-bucket activities in the place of oil spill; process and analyze the data of the results of material and information collection activity; make document and report for loss calculation work report. Second, the working group of loss impact calculation has the duty to compile the fixed procedures to 
calculate the impact of losses and to calculate the compensation for the impact of oil spillon marine and fishery resources. Third, the working group has the duty on the preparation of the compensation indictment document which contains the standard operating procedure of the indemnity compensation document, the contents of the indemnity document, the submission of documents to the National Command and Control Center for the Operation of Emergency Response of Oil Spill at the Sea (Puskodalnas) at the Ministry of Transportation, to assist the follow-up submitted by PUSKODALNAS until the approval of the compensation, to improve the field officer's ability to handle oil spills. Fourth, the working group of cleaning and rehabilitation mentoring has the duty to develop the operational procedures on coastal biota cleaning and rehabilitation assistance, to mitigate the impact handling of oil spill by cleaning the biota and coast, to provide assistance to the implementation of compensation to the community and the implementation of marine and fishery resource rehabilitation, to monitor and examine the post-occurrence of oil spill and to make documentation and report.

The field officer is in charge of monitoring activities by operating a 24-hour oil spill monitoring system for 7 days a week, receiving reports from the community, submitting reports to monitoring, reporting and indemnification working groups and database working groups, collecting materials and information, taking samples, data and information as the initial evidence after the oil spill, facilitating group work activities in the field and coordinating with relevant agencies. This team was formed only for the implementation of oil spills in Riau Islands and Jakarta.

The KKP has a Standard Operating Procedure (SOP) for calculating the impact of losses in the context of impact mitigation for the prevention of oil spill impact to marine and fishery resources. The identification of the impact of oil spill on the users and utilization of marine and fishery resources based on ecosystem mentions an ecosystem function including coastal areas in some groups, i.e.; regulatory functions in which ecosystems are capable of managing important ecological processes in nature, habitat functions in which ecosystems are home or living places for plants and animals, production function in which ecosystems perform photosynthesis to convert nutrients into energy and subsequently eaten by other living biomass, and information functions in which ecosystems provide reference functions and can serve as a place for relaxation, spiritual and recreational enrichment. The ecosystem functions then form the goods and services which are beneficial and have economic values to humans. [10]Calculating the impact of the oil spill and its loss value according to this SOP will depend on the quantity and intensity of the oil spill volume. If the amount of spill is very high, the oil spill in the sea affects the quality of the surrounding waters which of course will disturb the biota life in it. More significant impacts will be felt when the oil spill reaches the coastal areas as coastal areas contain many important ecosystems and have a direct impact on the decline in the benefits and services of the ecosystem. [11]

The calculation of the total value of oil spill loss impacts consists of three components; i.e.: Compensable value, restoration cost, and assessment cost. Compensable value is anything received in physical or non-physical forms and must be calculated and given to the party or person who is generally an object affected by an oil spill. Compensable value consists of several values which are based on the type of utilization and the utilization of marine and fishery resources in the areas exposed to the oil spill, consisting of; lost economic value from fishing activities (coral reef ecosystem, mangrove and marine), lost economic value from cultivation activity (land, brackish and sea), lost economic value from marine activity, economic value from the damage of coastal ecosystem (mangrove, coral reefs and seagrasses), lost economic value of fishery processing activities, lost economic value from the aesthetics of the coastal environment, lost economic value from cultivation 
production means (keramba, ponds, etc.), lost economic value from the damage of marine tourism facilities and infrastructures. [12]

In addition to the compensation calculation, the KKP's SOP regulates the cost of recovery as part of pollution control and/ or environmental damage that is carried out in the framework of environmental conservation. The cost of restoration is defined as the costs incurred in recovery efforts to make the environment or parts of it function again as it was.[13] The cost of recovery or restitutio in integrum in the lawsuit of unlawful act means the measure of damage or restoration of damage as it was in the original state before the occurrence of an act against the law.In other hand, in the contract, it is intended to be restored to the state of the contract when it is not violated. [14]

The polluted and/ or damaged environments must be restored wherever possible prior to the pollution and/ or damage to the environment. This environmental restoration act applies to the public environment which is the right and authority of the government and the community that includes the rights and powers of individuals and groups of people. The cost of recovery due to oil spill is divided into two; the cost of cleaning up oil spills on coastal and marine areas and the cost of rehabilitation of ecosystem environments (mangroves, coral reefs and seagrasses). [15]

The SOP made by the KKP in 2016 is a serious progress for the KKP in taking into account the sustainability of marine ecosystems as the carrying capacity of captive fishery in coastal areas. Before the SOP was established, the KKP has not played an active role in protecting marine ecosystems as a carrying capacity of captive fishery, in the case of oil pollution by tankers and post-events. In this SOP, the KKP began to formulate a mechanism for handling compensation in the event of pollution and the sustainability of pollution through restitutio in integrum. The step forward of the KKP's active role is of course still to be fought since the pollution completion committee is at the minister of transportation, and the KKP is only a member in the emergency oil spill response team at sea.

\section{Conclusion}

The role of the Ministry of Marine and Fishery in the Marine Environment Protection from Oil Pollution by Sea Tankers in the Indonesian Legal System is still very limited because the Ministry of Marine and Fishery is only a member of the National Team for Emergency Response of Oil Spill at Sea (the Regulation of the President of the Republic Indonesia Number 109 of 2006 on Emergency Response of Oil Spill at Sea). The Ministry of Marine and Fishery only has the authority to map sea losses related to fish, mangroves, coral reefs and seagrass beds. The other environmental losses are the authority of the Ministry of the Environment which is positioned as the vice chairman, while the position of the chairman is the responsibility of the Ministry of Transportation. However, with the preparation of the Standard Operational Procedure (SOP) for the Calculation of Loss Impacts in Order to Overcome the Impact of Oil Spill on Marine Resources and Fisheries, it is expected that the Ministry of Marine and Fishery can play more active role in calculating the loss of fishery and the carrying capacity of the ecosystem, and even the recovery compensation for the oil pollution caused by tankers.

\section{References}

1G. R. Lilley. Prosiding Lokakarya Reformasi Hukum di bidang Pengelolaan Sumber Daya Alam.(Cetakan I, ICEL, Pustaka Pelajar Offset, 1999) 
2Pusat Pendidikan Kelautan dan Perikanan Badan Pengembangan SDM Kelautan dan Perikanan Kementrian Kelautan dan Perikanan, Blue EconomyGoes to Campus, p. 2,4 Kementrian Kelautan dan Perikanan. (2014)

3Albert Gore. Department of States Dispatch, 6,2 (1995)

4Siregar.Workshop Forum Rektor Indonesia USU. (2015)

5Lampiran Kebijakan Kelautan Indonesia, Naskah Akademik Tentang Rancangan Undangundang Kelautan, Kementrian Koordinator Bidang Kemaritiman Republik Indonesia(2017)

6Ibid

7GregoriusMagnisFinesso, SaatNelayanTerpaksa "Menjala" Minyak, Beta KOMPAS online, Available from http://print.kompas.com/baca/2015/05/29/Saat-Nelayan-Terpaksa\%E2\%80\%9D-Minyak, Accessed July 172015.

8DaudSilalahi.

HukumLingkunganDalamSistemPenegakkanHukumLingkungan Indonesia(Alumni, Bandung. p. 14.2001)

9Cross, Michael, Hamer, Mick, March.New Scientist.133, 3-4 (1992)

10De Groot R.S. M.A. Wilson, R.Mj. Boumans. Ecological Economics. 41, 393-408 (2002)

11Pusat Penelitian Sosial Ekonomi Kelautan dan Perikanan Badan Penelitian dan Pengembangan Kelautan dan Perikanan, Kementrian Kelautan dan Perikanan, Kajian Penyusunan Standar Operasional Prosedur (SOP) Perhitungan Dampak Kerugian Dalam Rangka Penanggulangan Dampak Tumpahan Minyak Terhadap Sumber Daya Kelautan dan Perikanan, p.8 (2016)

12 Ibid. p.16

13 M. Yahya Harahap, Kekuasaan Mahkamah Agung Pemeriksaan Kasasi dan Peninjauan Kembali Perkara Perdata, Sinar Grafika, Jakarta. p. 5-6 (2008)

14 Henry Campbell Black, Black's Law Dictionary with Pronunciations, Definitions of the Terms and Phrase of American and English Jurisprudence, Ancient and Modern, St. Paul Minn, West Publishing Co. p. 1313(1990).

15Pusat Penelitian Sosial Ekonomi Kelautan dan Perikanan Badan Penelitian dan Pengembangan Kelautan dan Perikanan, Kementrian Kelautan dan Perikanan, Op.Cit. p.1718 